\title{
OORRECTION
}

\section{Correction to: Novel and potent inhibitors targeting DHODH are broad-spectrum antivirals against RNA viruses including newly-emerged coronavirus SARS-CoV-2}

Rui Xiong ${ }^{2}$, Leike Zhang ${ }^{3}$, Shiliang Li ${ }^{2}$ (1), Yuan Sun ${ }^{3}$, Minyi Ding ${ }^{2}$, Yong Wang ${ }^{1}$, Yongliang Zhao', Yan $\mathrm{Wu}^{3}$, Weijuan Shang ${ }^{3}$, Xiaming Jiang ${ }^{3}$, Jiwei Shan ${ }^{2}$, Zihao Shen ${ }^{2}, Y_{i}$ Tong $^{2}$, Liuxin Xu ${ }^{2}$, Yu Chen ${ }^{1}$, Yingle Liu ${ }^{1}$, Gang Zou ${ }^{4}$, Dimitri Lavillette ${ }^{4}$, Zhenjiang Zhao ${ }^{2}$, Rui Wang ${ }^{2}$, Lili Zhu ${ }^{(\mathbb{D}}$, Gengfu Xiao ${ }^{3}, \mathrm{Ke} \mathrm{Lan}^{1}$, Honglin $\mathrm{Li}^{2 \bowtie}\left(\mathbb{D}, \mathrm{Ke} \mathrm{Xu}^{1,4 \bowtie}\right.$

${ }^{1}$ State Key Laboratory of Virology, College of Life Sciences, Wuhan University, Wuhan 430072, China

2 Shanghai Key Laboratory of New Drug Design, State Key Laboratory of Bioreactor Engineering, School of Pharmacy, East China University of Science and Technology, Shanghai 200237, China

${ }^{3}$ State Key Laboratory of Virology, Wuhan Institute of Virology, Center for Biosafety Mega-Science, Chinese Academy of Sciences, Wuhan 430071, China

${ }^{4}$ CAS Key Laboratory of Molecular Virology and Immunology, Institut Pasteur of Shanghai, University of Chinese Academy of Sciences, Chinese Academy of Sciences, Shanghai 200031, China

$\triangle$ Correspondence: hlli@ecust.edu.cn (H. Li), xuke03@whu.edu.cn (K. Xu)

CORRECTION TO: PROTEIN CELL 2020,

\section{1(10):723-739}

HTTPS://DOI.ORG/10.1007/S13238-020-00768-W

In the original publication the author's name 'Dimitri Lavillete' is published incorrectly. The correct author name should be spelt as 'Dimitri Lavillette' is provided in this correction.

\section{OPEN ACCESS}

This article is licensed under a Creative Commons Attribution 4.0 International License, which permits use, sharing, adaptation, distribution and reproduction in any medium or format, as long as you give appropriate credit to the original author(s) and the source, provide a link to the Creative Commons licence, and indicate if changes were made. The images or other third party material in this article are included in the article's Creative Commons licence, unless indicated otherwise in a credit line to the material. If material is not included in the article's Creative Commons licence and your intended use is not permitted by statutory regulation or exceeds the permitted use, you will need to obtain permission directly from the copyright holder. To view a copy of this licence, visit http:// creativecommons.org/licenses/by/4.0/. 